\title{
The introduction of tree and shrub species in the central district of Zanjan county town
}

\author{
Zohreh Toghranegar \& Mahnaz Vafadar \\ Department of Biology, Faculty of Science, University of Zanjan, Zanjan, Iran \\ Correspondent author: Mahnaz Vafadar, vafadar@znu.ac.ir
}

\begin{abstract}
Floristic study is one of the most efficient methods of gaining knowledge about biological capacities, as well as management and conservation of plant genetic resources in ecological systems. Zanjan county town is located in a mountainous region with an area of $6763 \mathrm{~km}^{2}$ and the average altitude of $1663 \mathrm{~m}$.a.s.l. Its favorable vegetation diversity is the result of suitable ecological conditions, diverse habitats and appropriate water resources in the region. The central district of Zanjan county town, with an area of $2600.2 \mathrm{~km}^{2}$, was chosen as a representative to show tree and woody shrub species diversity. In order to identify tree and shrub species, life forms and chorology of plants, samples were collected by the conventional method of floristic studies and were, then, identified using taxonomic references. In total, there were 122 tree and woody shrub species, belonging to 76 genera and 39 families, in the studied area. The richest families included Rosaceae (29 species) and Oleaceae (9 species), which comprised $31.15 \%$ of the arboreal and woody shrub species. Mesophanerophytes $(37.7 \%)$ and microphanerophytes $(32.79 \%)$ were the dominant life forms in the area studied as determined by the Raunkiaer method. The Irano-Turanian vegetative elements were the most important elements in this area based on Zohary approach. Prunus lycioides was found to be endemic to Iran.
\end{abstract}

Keywords. floristic study, life form, shrubs, trees, vegetative elements 
2004). به منظور معرفى مجموعه گياهان درختى و درختجهاى يرديس موسسه تحقيقات كياهيزشكى كشور، يزوهشى انجام شد.

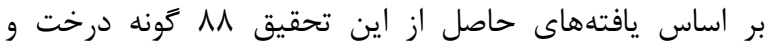

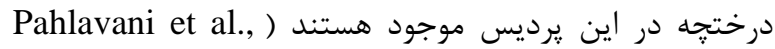

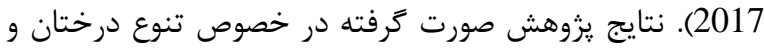

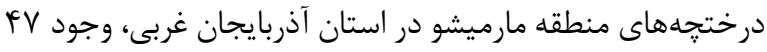

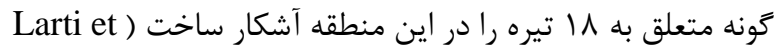

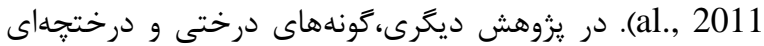

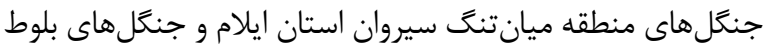

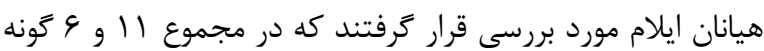
درختى در اين جنكل ها معرفى شدند (Hosseini, 2014, 2016).

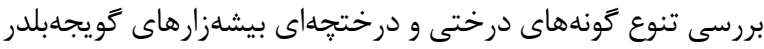

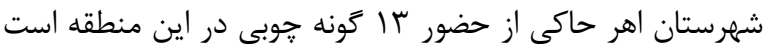
(Ghanbari\& Shaidai, 2018). همرجنين بررسى تنوع گونهاى

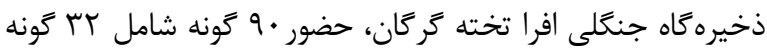

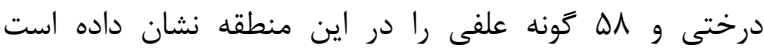
Esmailzadeh et al., 2012)

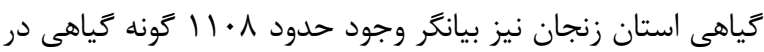
اين منطقه از شمال غرب كشوراست (Mousavi, 2000).

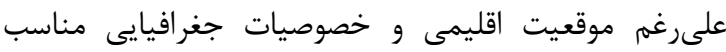
شهرستان زنجان، وجود زيستكاههاى متنوع، منابع آبى نسبتا

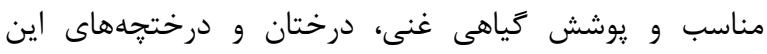
شهرستان به صورت اختصاصى مورد مطالعه قرار نكرفتهاند. از

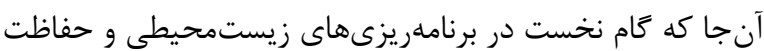

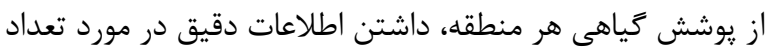

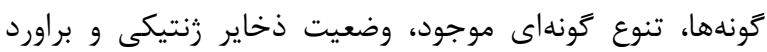

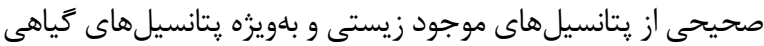

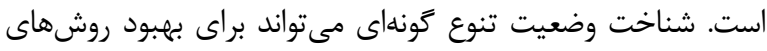
حفاظت از آنها، تلاش جهت افزايش اين تنوع و نيز جلوكيرى از

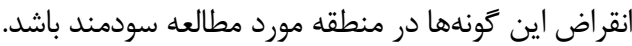

\section{موادوروشها}

ويزگى هاى منطقه مورد مطالعه: شهرستان زنجان در مركز استان

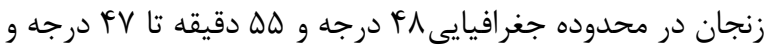

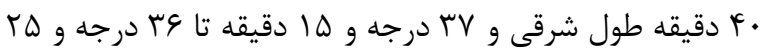

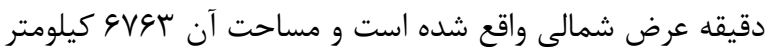
مربع است. اين شهرستان از شمال به استان آذربايجان شرقى، از

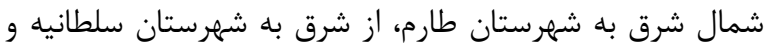

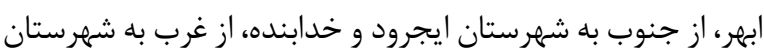

مقلهم

شناسايى و حفاظت از يوشش كياهى و تنوع كَونهاى هر منطقه، به سبب كاركرد آن در خرخه غذايى، جلوكيرى از فرسايش خاك و احياء محيط، از اولويتهاى زيست محيطى بهشمار مى دآيد آندايد Proença et al., 2017) مولفههاى تنوع زيستى بوده (Hui \& Pommerening, 2014)

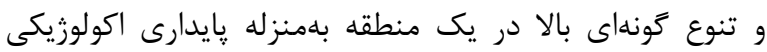

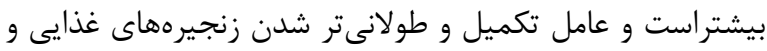

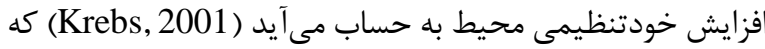
نابودى هر يك از آنها باعث به هم خوردن تعادئ بهادل حياتى طبيعت

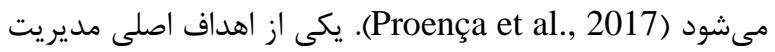
منابع طبيعى، حفظ تنوع گياهى در اكوسيستم در سه سطح

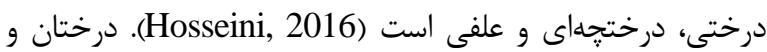

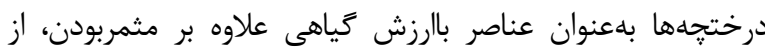

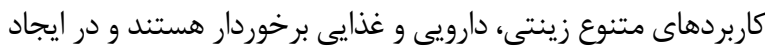
فضاى سبز، تلطيف هوا، تعديل آب و هواى منطقه و كنترل اقليم،

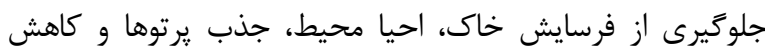

آلودگى هاى صوتى نقش دارند (Momen Roomiany, 2000). بررسى يوشش گياهى يك منطقه به صورت محلى جهت

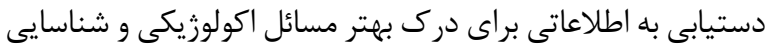

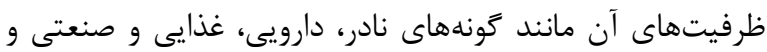

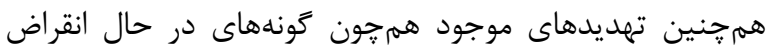

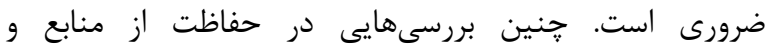
اكوسيستمهاى طبيعى و در توسعه پايدار نقش موثرى دارند. كشور يهناور ايران نيز به دليل تنوع وسيع اقليمى، تويوكرافى، يِيشينه

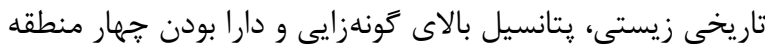

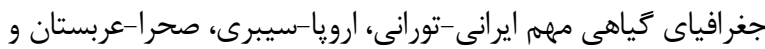

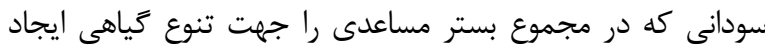
كرده، موضوع مطالعات فلورستيك، يوشش و و جغرافياى گياهى

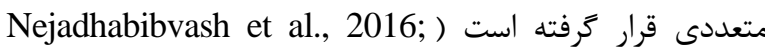
Zohary, 1973 درخت و درختجه از ديرباز مفهومى خاص و برارزش براى ساكنان فلات خشك مركزى ايران داشته است. درخان.

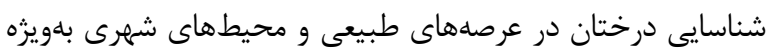
يارك دها، يرديسها، اماكن تاريخى و بناهاى داراى ارزش خاص خاص نيز مورد توجه بوده است (Pahlavani et al., 2017).

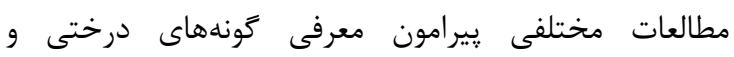
درختجهاى در مناطق مختلف كشور انجام شده است. تعداد كَونهاى درختان و درختجههاى ايران (اعم از خودرو و كاشته

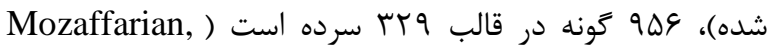


هرباريوم دانشكده علوم دانشگاه زنجان نكَهدارى مىشوند. اين

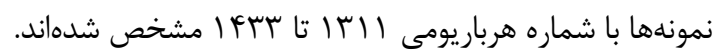

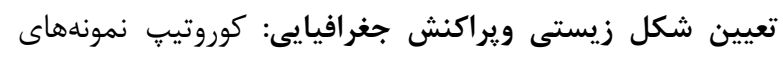

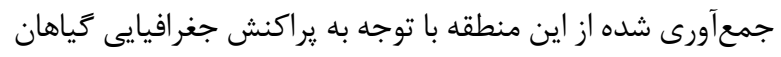

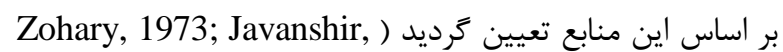
1976; Takhtajan, 1986; Mozaffarian, 2004; Yusefi, 2006). اشكال زيستى نمونههاى درختى و درختجهاى براساس

سيستم طبقهبندى رانكيه (Raunkiaer, 1934) مشخص شد.

\section{نتابتج}

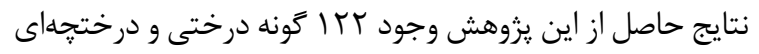
متعلق به V9 سرده و وץ تيره گياهى راد ادر منطقه مورد مطالعه نشان

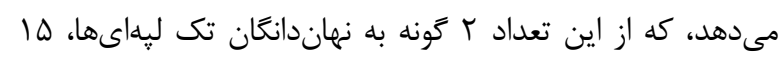

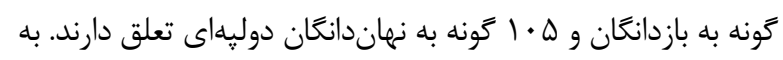
اين ترتيب بيشترين تعداد گونهها متعلق به دوليهاى بها است (جدول

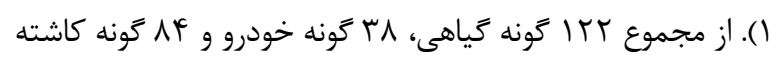
شده هستند. تيرههاى كلسرخيان (Rosaceae) با وج زونه

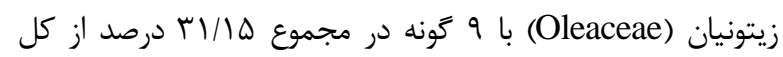
گ زونهها را تشكيل داده و غنىترين تيرههاى گياهى در منطقه مورد

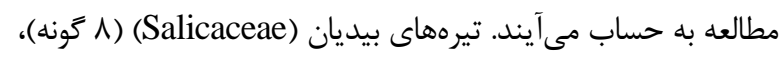

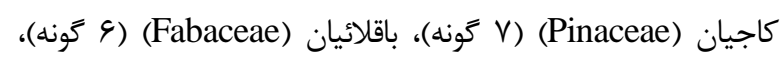

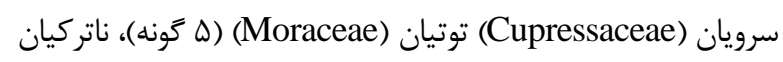

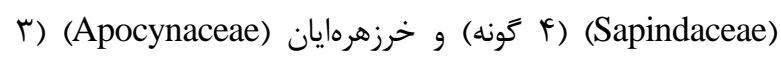
گونه) در رتبههاى بعدى قرار دارند (شكل

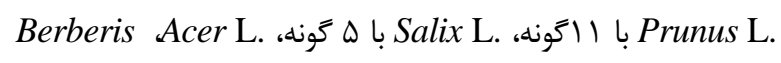
gPyrus L. ‘Populus L.،Crataegus L. ،Cotoneaster L. L.

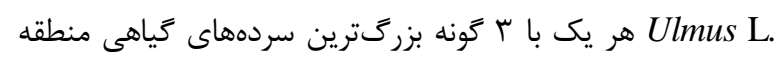
مورد بررسى هستند (شكل أ). براساس سيستم طبقهبندى رانكيه،

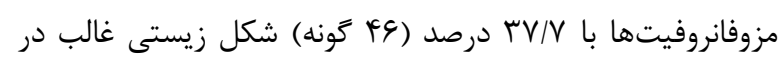

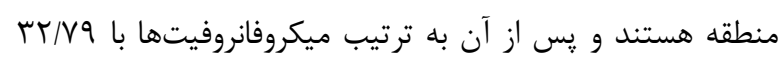

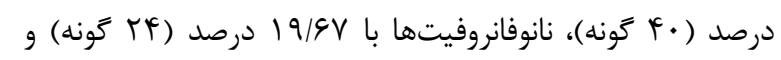

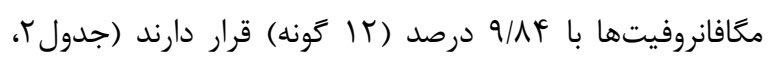

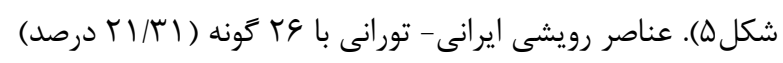

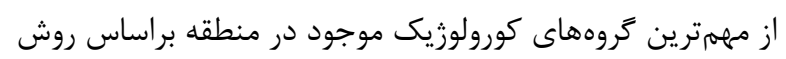
زهرى (Zohary, 1973) هستند. ساير مناطق فيتوجغرافيايى به

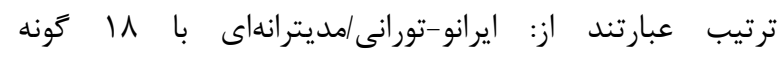

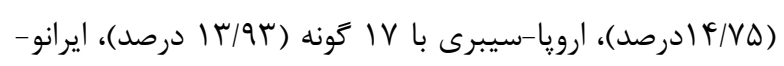

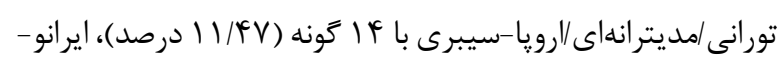

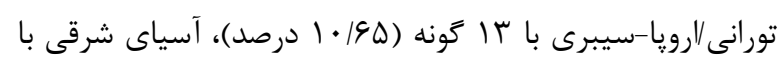

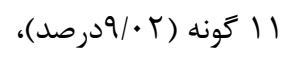

ماهنشان و از شمال غرب به شهرستان ميانه محدود مى

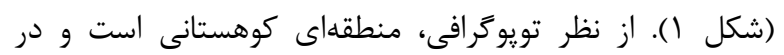

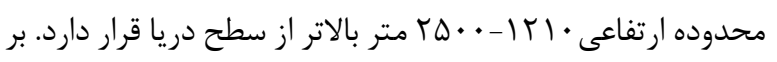

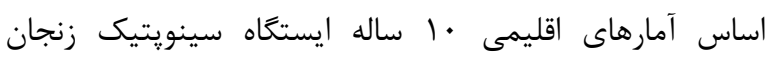

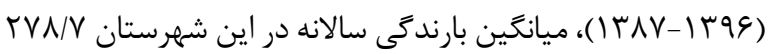
ميلىمتر است. حداكثر بارندكى در فروردين ماه به ميزان اله

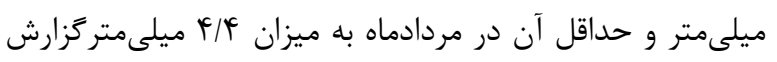

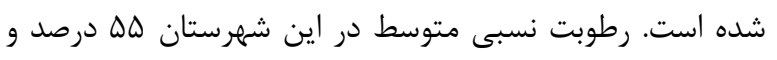

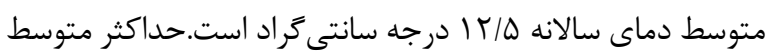

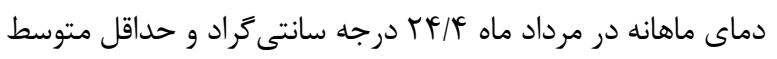

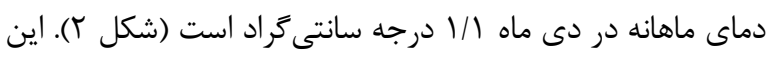
منطقه داراى تابستان هاى معتدل و زمستانهاى سرد است. بر اساس داس دان

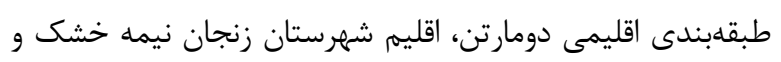

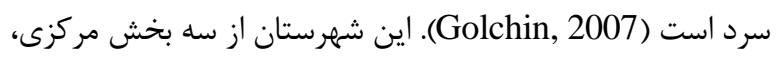

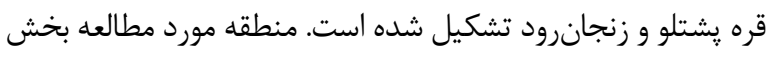

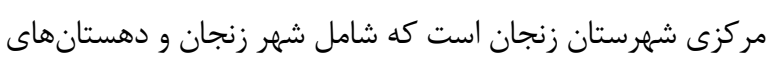

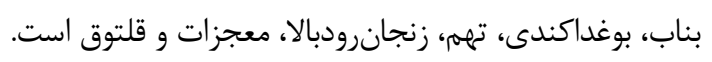
جمع آورى نمونهها: در اين يزوهش، يس إز تعيين حوضه زئه مورد مطالعه

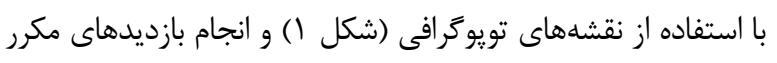

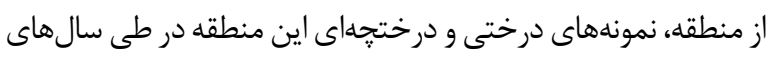

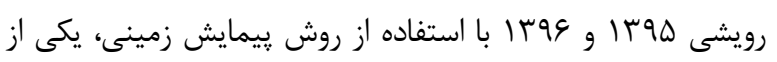
روشهاى مرسوم مطالعات فلوريستيك، جمعآورى شد (جدول با ب) و

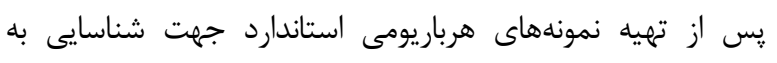

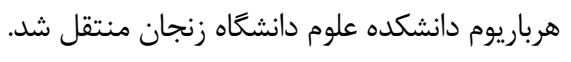

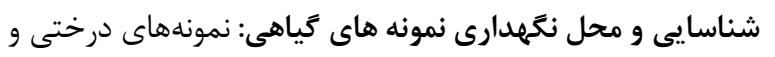

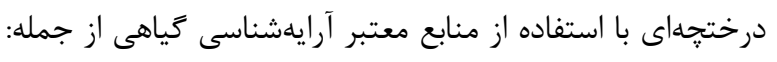

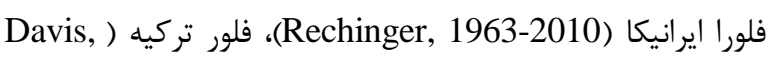

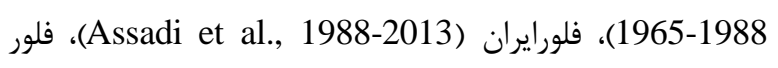

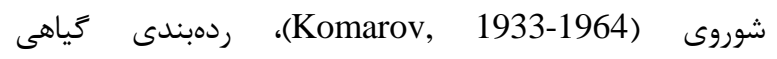

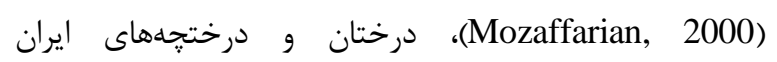
و شناخت گياهان دارويى و معطر ايران (Mozaffarian, 2004) (Mozaffarian, 2012) سردهها با سيستم طبقهبندى APG IV) مطابقت داده شدند. درستى آخرين نام يذيرفته شده براى آرايههاى گياهى

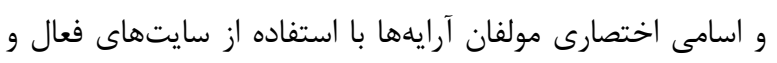
معتبر اينترنتى از جمله The plant list (2013) و نيز با نمايه بين المللى نامهاى گياهى (IPNI, 2016) تطبيق و يكسانسازى شدند. نامخذارى فارسى گياهان نيز بر اساس فرهنگ نامهاى خياهان ايران (Mozaffarian, 1998) (Mozaffarian, 2004) 

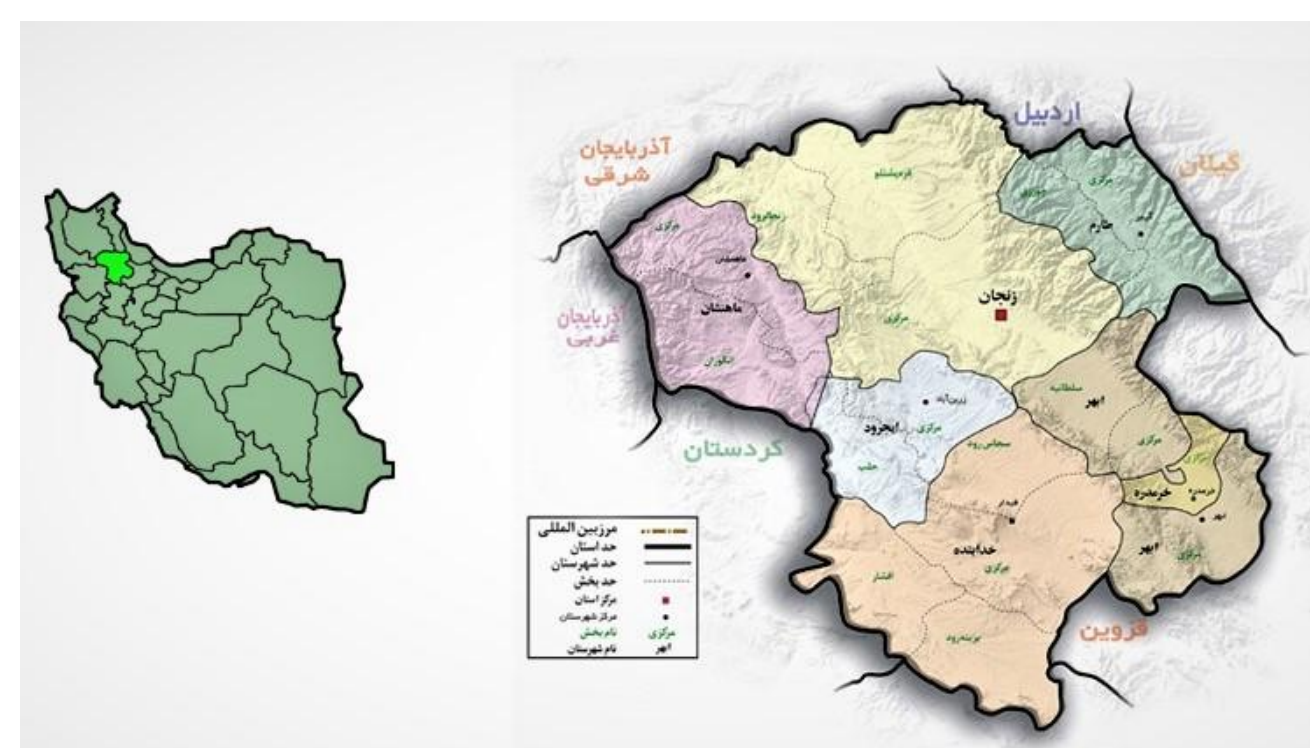

شكل ا-بخش مركزى شهرستان زنجان: موقعيت منطقه مورد مطالعه دراستان زنجان و ايران (اقتباس از سازمان جهادكشاورزى استان زنجان، مديريت آبخيزدارى). Fig. 1. Central district of Zanjan county town: Location of the study area in Zanjan Province and Iran (Source: Agricultural Jihad Organization of Zanjan Province, Watershed management).

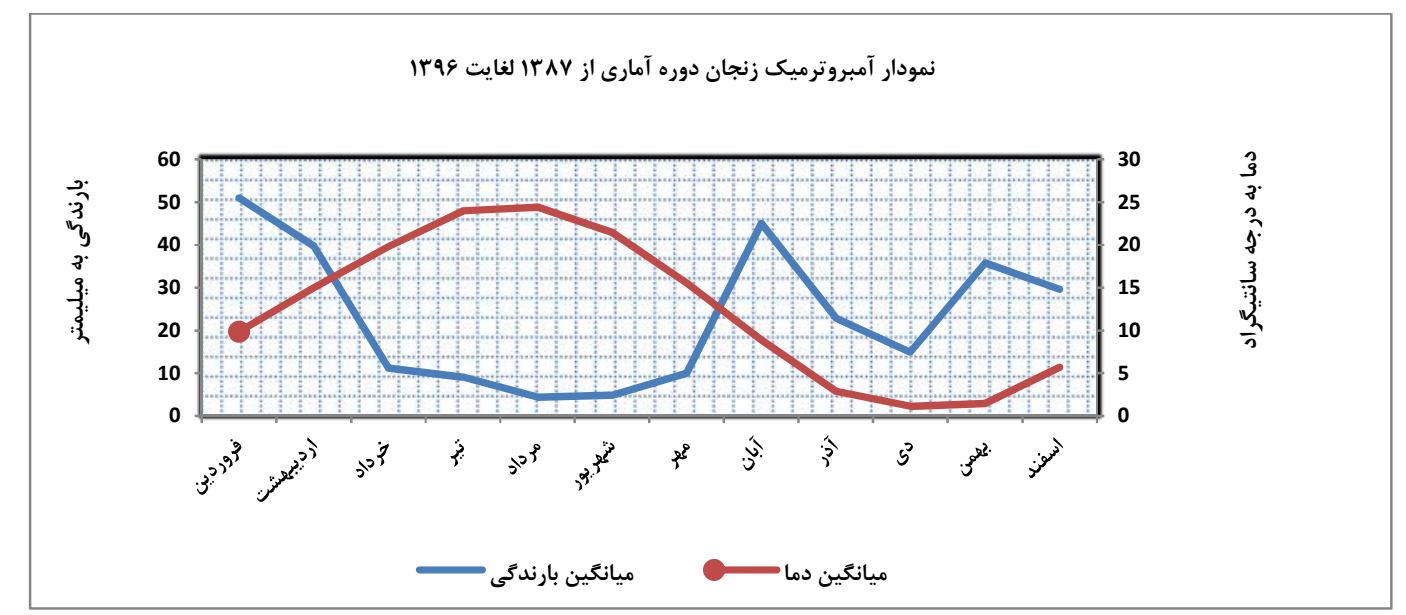

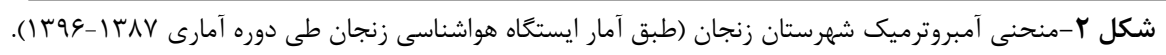

Fig. 2. Ombrothermic curve of Zanjan county town (According to the statistics of Zanjan weather station during the statistical period of 2008-2017).

$$
\text { جدول ا-تعداد گونههاى گروههاى عمده گياهى بخش مركزى شهرستان زنجان. }
$$

Table 1. The number of species in major groups of plants in the central district of Zanjan county town.

\begin{tabular}{|c|c|c|c|}
\hline تعدادكّونه & تعدادسرده & تعدادتيره & كروههاى تياهى \\
\hline 10 & v & $r$ & بازدانعان \\
\hline r & $r$ & $r$ & تهليه نهانكان \\
\hline 1.0 & $9 V$ & $r f$ & نهاندانكًان \\
\hline ITr & ve & rq & تعدادكل \\
\hline
\end{tabular}




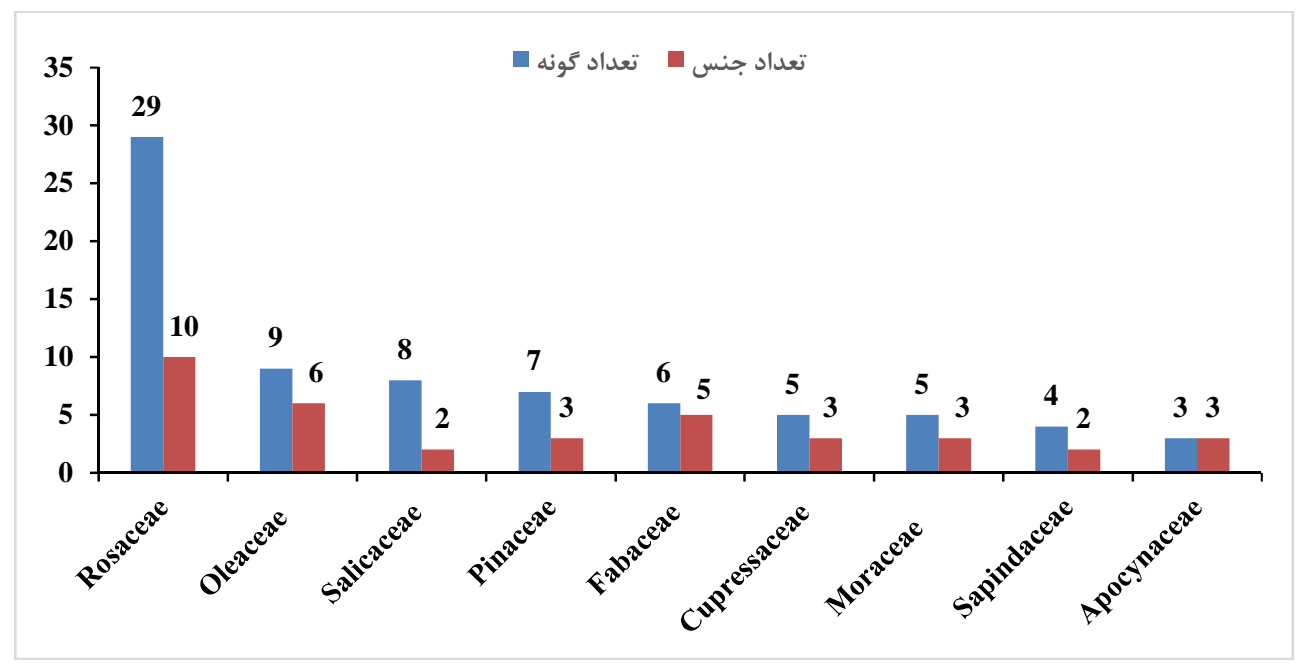

شكل ش-نموداربزركترين تيرههاى گياهى براساس تعداد سرده و گونه در بخش مركزى شهرستان زنجان

Fig. 3. Largest plant families according to the number of genera and species in central district of Zanjan county town.

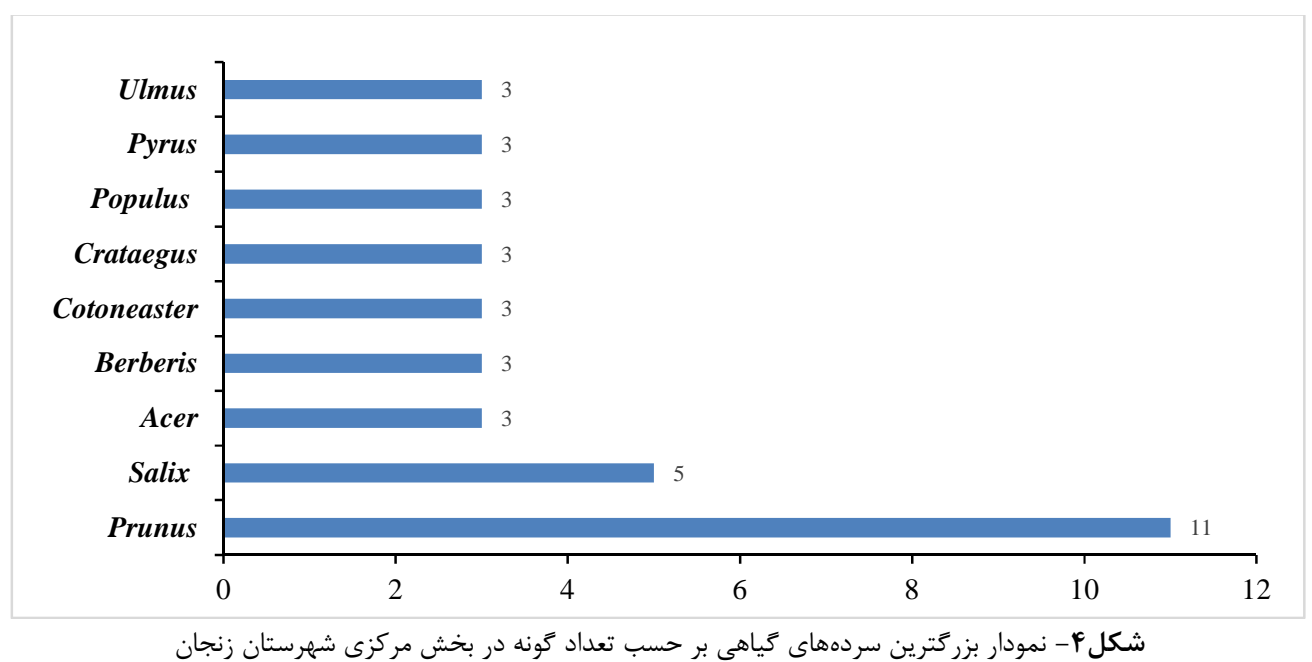

Fig. 4. Largest genera according to the number of species in central district of Zanjan county town.

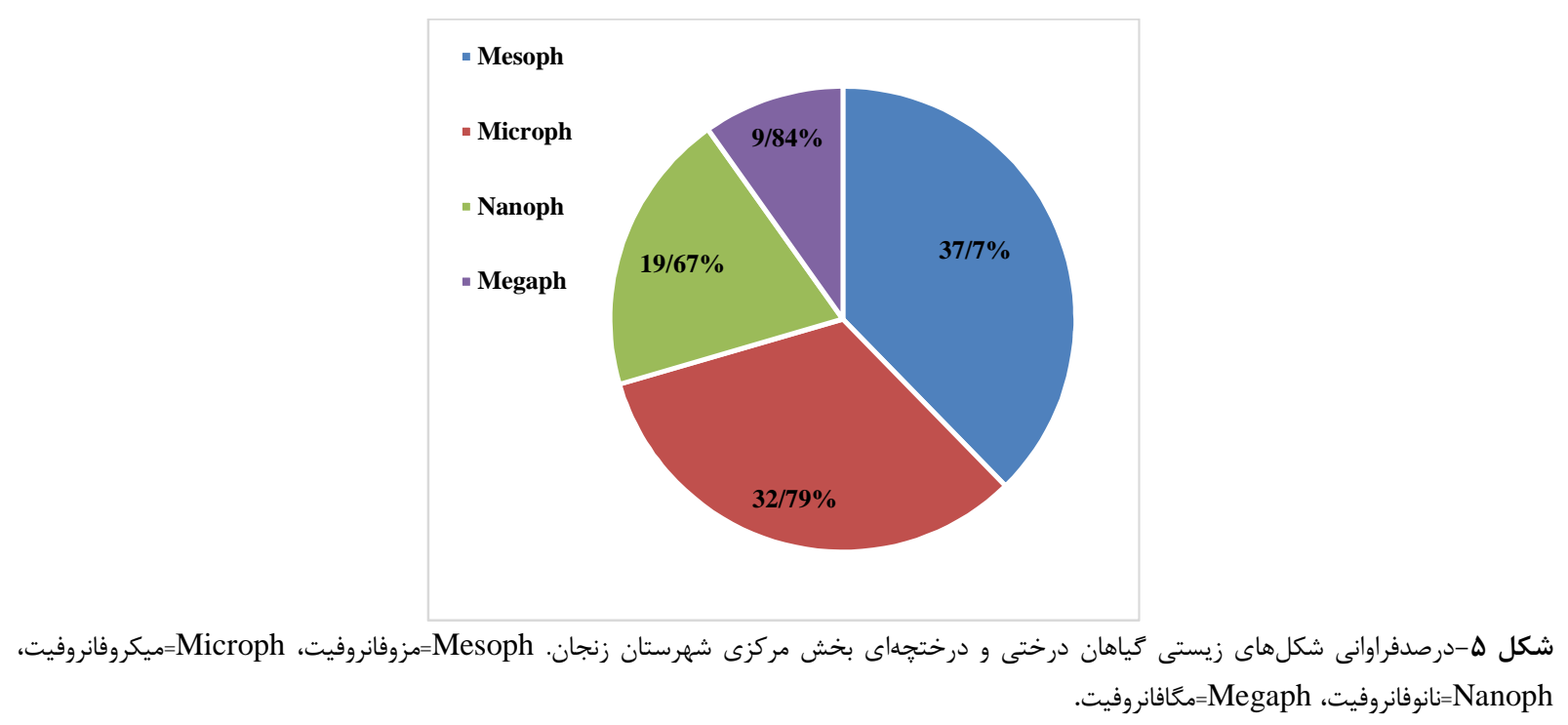

Fig. 5. Frequncy of life forms of tree and shrub species in central district of Zanjan county town. Mesoph=Mesophanerophytes, Microph=Microphanerophytes, Nanoph=Nanophanerophytes, Megaph=Megaphanerophytes. 

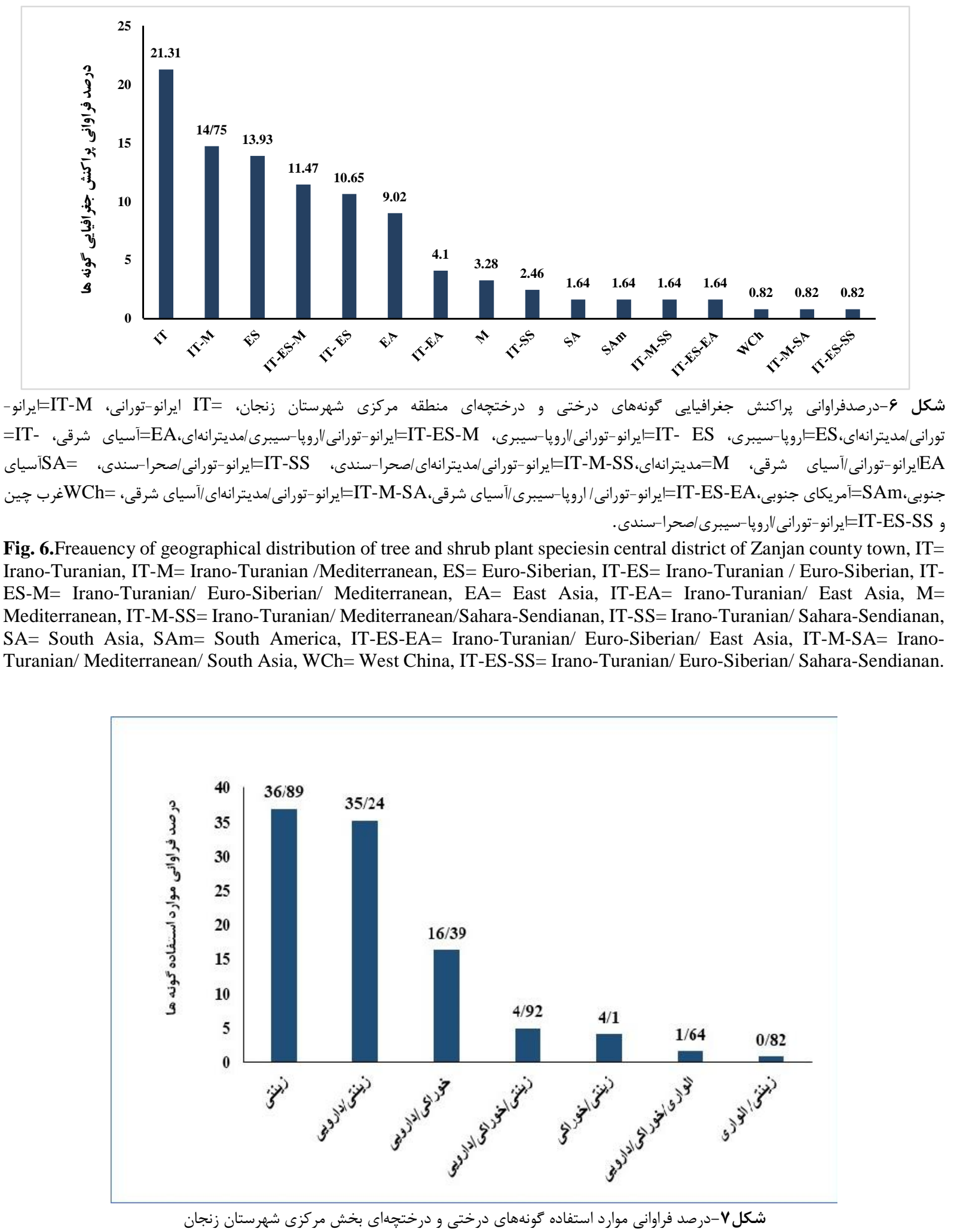

Fig. 7. Freauency of usages of tree and shrub plant speciesin central district of Zanjan Zanjan county town. 
جدول r- فهرست اسامى علمى كونه ها، فرم زيستى، يراكنش جغرافيايى، كاشته شده يا خودرو بودن و موارد استفاده درختان و درختحههاى شناسايى شده

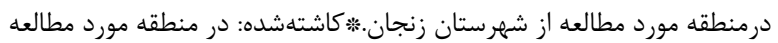

Table 2. List of scientific names of species and their life-form, geographical distribution, cultivated or wild plants, usages of tree and shrub plant species in the studied area in Zanjan county town, *Cultivated: in the studied area and other regions of the Country

\begin{tabular}{|c|c|c|c|c|c|c|c|}
\hline رديف & 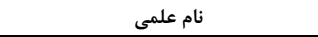 & 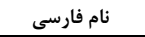 & نام محلى & فرم زيستى & يراكنش جغرافيايى & نوع رويش & 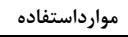 \\
\hline \multicolumn{8}{|c|}{ آدوكساسه Adoxaceae } \\
\hline 1 & Sambucus nigra $\mathrm{L}$. & 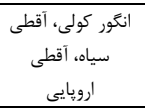 & - & 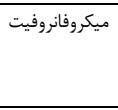 & ارويا - سيبرى، ايرانو -تورانى & كاشته شده & زينتى- داروئى \\
\hline$r$ & Viburnum opulus L. & بداغ، بداغ جنكلى & كرمهو & ميكروفانروفيت & ارويا - سيبرى & كاشته شده & زينتى- داروئى \\
\hline \multicolumn{8}{|c|}{ Amaranthaceae تاجخروسيان } \\
\hline r & Atriplex canescens (Pursh) Nutt. & 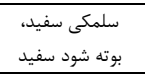 & - & 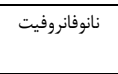 & ايرانو -تورانى & كاشته شده & زينتى، خوراكى- \\
\hline f & $\begin{array}{l}\text { Haloxylon persicumBunge ex } \\
\text { Boiss. \& Buhse }\end{array}$ & زرد تاغ & - & ميكروفانروفيت & ايرانو -تورانى، صحرا - سندى & كاشته شده & زينتى \\
\hline \multicolumn{8}{|c|}{ هبتهئيان Anacardiaceae } \\
\hline$\Delta$ & Cotinus coggygria Scop. & مرخت بر & زينج، زنج & ميكروفانروفيت & ارويا - سيبرى، ايرانو -تورانى & كاشته شده & زينتى- داروئى \\
\hline \multicolumn{8}{|c|}{ خرزهرهايان Apocynaceae } \\
\hline 4 & Nerium oleander L. & خرزهره & & 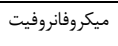 & ايرانو -تورانى & كاشته شده & زينتى- داروئى \\
\hline v & Trachomitum venetum Woodson & قيطانى & & 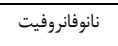 & ارويا - سيبرى، ايرانو -تورانى & كاشته شده & زينتى \\
\hline$\wedge$ & Vincamajor $\mathrm{L}$. & ي بيج تلكرافى & & 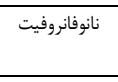 & ارويا - سيبرى، ايرانو -تورانى، & كاشته شده & زينتى- داروئى \\
\hline \multicolumn{8}{|c|}{ كاسنيان Asteraceae } \\
\hline 9 & Yucca gloriosa L. & ز زنكولهاى، يوكا & & ميكروفانروفيت & ارويا - سيبرى & كاشته شده & زينتى- داروئى \\
\hline \multicolumn{8}{|c|}{ آسفودلاسه Asphodelaceae } \\
\hline 1. & Hemerocallis fulva $\mathrm{L}$. & زنبق رشتى & & 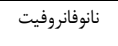 & ايرانو -تورانى، آسياى شرقى & كاشته شده & زينتى- داروئى \\
\hline \multicolumn{8}{|c|}{ كاسنيان Asteraceae } \\
\hline 11 & Solidago nemoralis Aiton & علف طلايى & & ن انوفانروفيت & ارويا - سيبرى & كاشته شده & زينتى \\
\hline \multicolumn{8}{|c|}{ عشقدئيان Araliaceae } \\
\hline ir & Hedera helix $\mathrm{L}$. & عشقه & & مزوفانروفيت & ارويا - سيبرى، ايرانو -تورانى & كاشته شده & زينتى- داروئى \\
\hline ir & $\begin{array}{l}\text { Schefflera arboricola (Hayata) } \\
\text { Hayata ex Merr. }\end{array}$ & شفلرا & & ميكروفانروفيت & آسياى شرقى & كاشته شده & زينتى \\
\hline \multicolumn{8}{|c|}{ مطبق كاجيان Araucariaceae } \\
\hline if & $\begin{array}{l}\text { Araucaria araucana (Molina) } \\
\text { K.Koch }\end{array}$ & 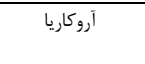 & - & مزوفانروفيت & آمر يكاى جنوبى & كاشته شده & زينتى \\
\hline 10 & $\begin{array}{l}\text { Araucaria heterophylla (Salisb.) } \\
\text { Franco }\end{array}$ & كاج مطبق & - & مكافانروفيت & ارويا - سيبرى & كاشته شده & 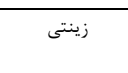 \\
\hline \multicolumn{8}{|c|}{ زرشكيان Berberidaceae } \\
\hline 19 & Berberis integerrima Bunge & زرشك زرافشانى & ز & ميكروفانروفيت & ايرانو -تورانى & 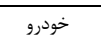 & زينتى- داروئى \\
\hline iv & $\begin{array}{l}\text { Berberis } \times \text { ottawensis } \\
\text { C.K.Schneid. }\end{array}$ & زرشك & - & نانوفانروفيت & آسياى شرقى & كاشته شده & زينتى - يرجين \\
\hline 11 & Berberis vulgaris $\mathrm{L}$. & زرشك & - & ميكروفانروفيت & ارويا - سيبرى، ايرانو -تورانى & كاشته شده & زينتى، خوراكى- \\
\hline \multicolumn{8}{|c|}{ توسكائيان Betulaceae } \\
\hline 19 & Corylus avellana $\mathrm{L}$. & فندق & فندخ & ميكروفانروفيت & ايرانو -تورانى، مديترانهاى & 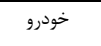 & خوراكى - داروئى \\
\hline \multicolumn{8}{|c|}{ Bيجاناريان Bignoniaceae } \\
\hline r. & Campsis radicans (L.) Seem. & يَيج انارى معمولى & & مزوفانروفيت & ارويا - سيبرى & كاشته شده & زينتى \\
\hline rI & Catalpa bignonioides Walter & كاتالا، جوالدوزكى & كَّىبوينيزى & مزوفانروفيت & ارويا - سيبرى & كاشته شده & زينتى- داروئى \\
\hline \multicolumn{8}{|c|}{ آقطيان Caprifoliaceae } \\
\hline Tr & Lonicera japonica Thunb. & ي يبج امين الدوله & شن & ميكروفانروفيت & آسياى شرقى & كاشته شده & زينتى- داروئى \\
\hline
\end{tabular}




\begin{tabular}{|c|c|c|c|c|c|c|c|}
\hline tr & $\begin{array}{l}\text { Symphoricarpos albus (L.) } \\
\text { S.F.Blake }\end{array}$ & مرواريد سفيد & - & نانوفانروفيت & ارويا - سيبرى & كاشته شده & زينتى \\
\hline \multicolumn{8}{|c|}{ كوشواركيان Celastraceae } \\
\hline TY & Euonymus japonicus Thunb. & شمشاد زاينى & - & ميكروفانروفيت & آسياى شرقى & كاشته شده & زينتى يرجين \\
\hline \multicolumn{8}{|c|}{ سرويان Cupressaceae } \\
\hline TQ & Cupressus arizonica Greene & سرو نقرهاى، سرو & - & مزوفانروفيت & ارويا - سيبرى & كاشته شده & زينتى- داروئى \\
\hline rq & Cupressus sempervirens $\mathrm{L}$. & سرو شيراز، زربين & - & مكافانروفيت & ايرانو-تورانى، مديترانهاى & كاشته شده & زينتى- داروئى \\
\hline Tr & Juniperus communis L. & ي ي يرو، اربس & جتنه & مزوفانروفيت & ارويا - سيبرى & كاشته شده & زينتى- داروئى \\
\hline r^ & Juniperus horizontalis Moench & ارس خزنده & - & 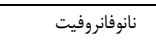 & ارويا - سيبرى & كاشته شده & 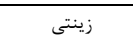 \\
\hline rq & Platycladus orientalis (L.) Franco & سرو طبرى، نوش & - & مزوفانروفيت & ايرانو -تورانى، ارويا - سيبرى، & كاشته شده & زينتى- داروئى \\
\hline \multicolumn{8}{|c|}{ سنجديان Elaeagnaceae } \\
\hline$r \cdot$ & Elaeagnus angustifolia $\mathrm{L}$. & سنجد & ايده & ميكروفانروفيت & ايرانو -تورانى & خودرو & خوراكى، داروئى- جوب \\
\hline \multicolumn{8}{|c|}{ ارمكيان Ephedraceae } \\
\hline$\mu_{1}$ & $\begin{array}{l}\text { Ephedra intermedia Schrenk \& } \\
\text { C.A.Mey. }\end{array}$ & ارمك ميانه & - & ن انوفانروفيت & ايرانو -تورانى، ارويا - سيبرى & خودرو & زينتى، داروئى- \\
\hline rt & Ephedra major Host & ارمك كبير، ارمك & - & نانوفانروفيت & ايرانو -تورانى، مديترانهاى & خودرو & زينتى، داروئى- \\
\hline \multicolumn{8}{|c|}{ Fabaceae باقلائيان } \\
\hline rr & Amorpha fruticosa $\mathrm{L}$. & نيلك & & 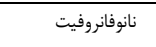 & ارويا - سيبرى & كاشته شده & زينتى \\
\hline ry & Cercis siliquastrum $\mathrm{L}$. & 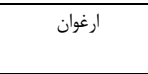 & & مزوفانروفيت & ارويا - سيبرى، ايرانو -تورانى، & كاشته شده & زينتى- داروئى \\
\hline ro & Robinia hispida L. & بنفش(صورتى) & & ميكروفانروفيت & ارويا - سيبرى & كاشته شده & 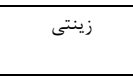 \\
\hline re & Robinia pseudoacacia $\mathrm{L}$. & اقاقيا & كولى الهبيسم & مزوفانروفيت & ارويا - سيبرى، ايرانو -تورانى، & كاشته شده & 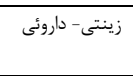 \\
\hline rv & Spartium junceum $\mathrm{L}$. & 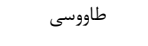 & & 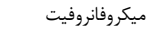 & ايرانو -تورانى، مديترانهاى & كاشته شده & 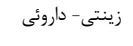 \\
\hline$r \wedge$ & Wisteria sinensis (Sims) Sweet & كاقليسين بنفش، & & 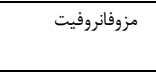 & ايرانو -تورانى، آسياى شرقى & كاشته شده & زينتى \\
\hline \multicolumn{8}{|c|}{ هيدرانرآسه Hydrangeaceae } \\
\hline rq & Deutzia scabra Thunb. & دوتسيا & & ميكروفانروفيت & ايرانو -تورانى، آسياى شرقى & كاشته شده & 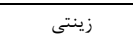 \\
\hline f. & Philadelphus coronarius L. & نركّ درختى & & ميكروفانروفيت & مديترانهاى & كاشته شده & زينتى \\
\hline \multicolumn{8}{|c|}{ كردوئيان Juglandaceae } \\
\hline +1 & Juglans regia $\mathrm{L}$. & كردو & جويز، كيردهان & مكافانروفيت & ايرانو -تورانى & كاشته شده & خوراكى - دارويى \\
\hline \multicolumn{8}{|c|}{ نعنائيان Lamiaceae } \\
\hline qr & Lavandula angustifolia Mill. & اسطوخودوس & & 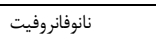 & مديترانهاى & كاشته شده & زينتى- داروئى \\
\hline rr & Salvia rosmarinus Spenn. & رزمارى & & 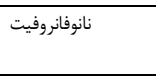 & مديترانهاى & كاشته شده & زينتى، آرايشى- \\
\hline \multicolumn{8}{|c|}{ حنائيان Lythraceae } \\
\hline fr & Lagerstroemia indica $\mathrm{L}$. & تورى & & ميكروفانروفيت & آسياى شرقى & كاشته شده & زينتى و دارويى \\
\hline$r \Delta$ & Punica granatum $\mathrm{L}$. & انارزينتى، انار & هينار & ميكروفانروفيت & ايرانو -تورانى، مديترانهاى، صحرا & 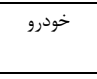 & زينتى، دارويى و \\
\hline \multicolumn{8}{|c|}{ Malvaceae ينيركيان } \\
\hline 48 & Hibiscus rosa-sinensis L. & ختمى خينى، زاينى & & ميكروفانروفيت & آسياى شرقى & كاشته شده & زينتى- داروئى \\
\hline fV & Hibiscus syriacus $\mathrm{L}$. & ختمى درختى & & ميكروفانروفيت & ايرانو -تورانى & كاشته شده & 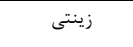 \\
\hline \multicolumn{8}{|c|}{ Moraceae توتيان } \\
\hline is & Ficus carica $\mathrm{L}$. & انجيرخوراكى & انجير & مزوفانروفيت & ايرانو -تورانى & كاشته شده & خوراكى- دارويى \\
\hline 49 & Ficus elastica Roxb. ex Hornem. & فيكوس & & مكافانروفيت & آسياى جنوبى و جنوب شرقى & كاشته شده & زينتى \\
\hline$\Delta \cdot$ & $\begin{array}{l}\text { Maclura pomifera (Raf.) } \\
\text { C.K.Schneid. }\end{array}$ & كاكوزا، توت & & مزوفانروفيت & ارويا - سيبرى & كاشته شده & 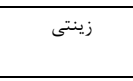 \\
\hline
\end{tabular}




\begin{tabular}{|c|c|c|c|c|c|c|c|}
\hline 01 & Morus alba $\mathrm{L}$. & توت سفيد، توت & 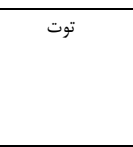 & مزوفانروفيت & ايرانو -تورانى & كاشته شده & 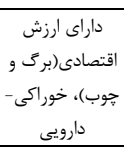 \\
\hline$\Delta T$ & Morus alba f. pendula Dipp. & 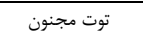 & & ميكروفانروفيت & ايرانو -تورانى، آسياى شرقى & كاشته شده & زينتى-خوراكى \\
\hline$\Delta r-1$ & Morus nigra $\mathrm{L}$. & 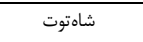 & شاهتوت، قرهتوت & 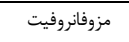 & ايرانو -تورانى & 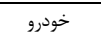 & خوراكى-دارويى \\
\hline \multicolumn{8}{|c|}{ كل كاغذيان Nyctaginaceae } \\
\hline$\Delta r$ & Bougainvillea spectabilis Willd. & كل كاغذى & & 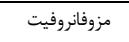 & آمريكاى جنوبى & كاشته شده & زينتى \\
\hline \multicolumn{8}{|c|}{ زيتونيان Oleaceae } \\
\hline$\Delta f$ & Forsythia $\times$ intermedia Zabel & 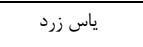 & & ميكروفانروفيت & آسياى شرقى & كاشته شده & زينتى- دارويى \\
\hline$\Delta \Delta$ & Fraxinus excelsior $\mathrm{L}$. & 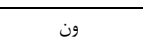 & 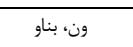 & 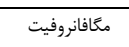 & ارويا - سيبرى، ايرانو -تورانى & 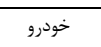 & زينتى- دارويى \\
\hline$\Delta s$ & Fraxinus rotundifolia Mill. & زبان كَجشك & 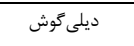 & 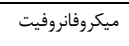 & ايرانو -تورانى، مديترانهاى & 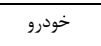 & زينتى \\
\hline$\Delta V$ & Jasminum fruticans $\mathrm{L}$. & ياسمن زرد & 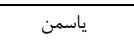 & 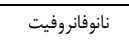 & ايرانو -تورانى، مديترانهاى & 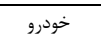 & 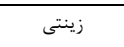 \\
\hline$\Delta \wedge$ & Jasminum officinale $\mathrm{L}$. & ياسمن سفيد، ياسن سفيد، & & 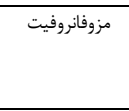 & ايرانو -تورانى، مديترانهاى & كاشته شده & زينتى- دارويى \\
\hline$\Delta 9$ & Ligustrum vulgare $\mathrm{L}$. & برك نو، مندار جه & 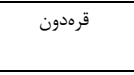 & ميكروفانروفيت & ارويا - سيبرى، ايرانو -تورانى، & كاشته شده & زينتى، يرجين - \\
\hline 4. & Olea europaea $\mathrm{L}$. & زيتون، زيتون & & 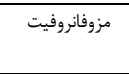 & ايرانو -تورانى، مديترانهاى & كاشته شده & خوراكى-دارويى \\
\hline 91 & Syringa persica $\mathrm{L}$. & ياس بنفش ايرانى & & ميكروفانروفيت & ايرانو -تورانى & كاشته شده & زينتى \\
\hline 8) & Syringa vulgaris $\mathrm{L}$. & ياس بنفش & & 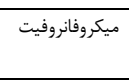 & مديترانهاى & كاشته شده & زينتى- دارويى \\
\hline \multicolumn{8}{|c|}{ كinaceae كاجيان } \\
\hline qr & $\begin{array}{l}\text { Cedrus atlantica (Endl.) } \\
\text { G.Manetti ex Carrière }\end{array}$ & سدر اطلسى & & مكافانروفيت & آسياى جنوبى & كاشته شده & زينتى-|قتصادى \\
\hline s4 & $\begin{array}{l}\text { Cedrus deodara (Roxb. ex } \\
\text { D.Don) G.Don }\end{array}$ & سدر مقدس، & & مكافانروفيت & ايرانو -تورانى، آسياى شرقى & كاشته شده & زينتى- دارويى \\
\hline $9 \Delta$ & Picea abies (L.) H.Karst. & 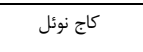 & & مكَافانروفيت & ارويا - سيبرى & كاشته شده & زينتى- دارويى \\
\hline 99 & Picea glauca (Moench) Voss & كاج نوئل كانادائى & & 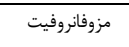 & ارويا - سيبرى & كاشته شده & زينتى \\
\hline $9 V$ & $\begin{array}{l}\text { Pinus brutia var. eldarica } \\
\text { (Medw.) Silba }\end{array}$ & كاج تهران، كاج & & 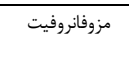 & ارويا - سيبرى، ايرانو -تورانى، & كاشته شده & زينتى \\
\hline $9 \Lambda$ & Pinus halepensis Mill. & كاج حلب & & 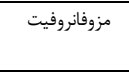 & ايرانو -تورانى، مديترانهاى، & كاشته شده & زينتى \\
\hline 99 & Pinus mugo Turra & كاج كوهى، كاج & & 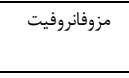 & آروّا - سيبرى، ايرانو -تورانى، & كاشته شده & زينتى \\
\hline \multicolumn{8}{|c|}{ جناريان Platanaceae } \\
\hline$v \cdot$ & Platanus orientalis $\mathrm{L}$. & جنار & קنار & مكافانروفيت & ايرانو -تورانى، مديترانهاى & 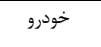 & زينتى \\
\hline \multicolumn{8}{|c|}{ Poaceae كندميان } \\
\hline VI & Miscanthus sinensis Andersson & ميسكانتوس & & نانوفانروفيت & آسياى شرقى & كاشته شده & زينتى \\
\hline \multicolumn{8}{|c|}{ Ranunculaceae آلالهايان } \\
\hline VT & Clematis vitalba $\mathrm{L}$. & كلماتيس سفيد & & 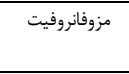 & ارويا - سيبرى، ايرانو -تورانى، & كاشته شده & زينتى- دارويى \\
\hline \multicolumn{8}{|c|}{ عنابيان Rhamnaceae } \\
\hline Vr & Rhamnus cathartica $\mathrm{L}$. & سبي، اشنكَّر & خلخال الجاره & ميكروفانروفيت & ارويا - سيبرى، ايرانو -تورانى، & 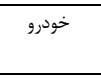 & زينتى- دارويى \\
\hline \multicolumn{8}{|c|}{ ملسرخيان Rosaceae } \\
\hline VF & $\begin{array}{l}\text { Chaenomeles japonica (Thunb.) } \\
\text { Lindl. ex Spach }\end{array}$ & 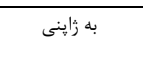 & & 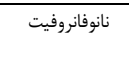 & آسياى شرقى & كاشته شده & 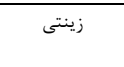 \\
\hline$v \Delta$ & Cotoneaster horizontalis Decne. & شيرخت & & 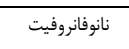 & غرب جين & كاشته شده & 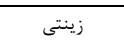 \\
\hline ve & Cotoneaster integerrimus Medik. & شيرخت برك & جالقيى & 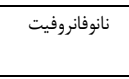 & ارويا - سيبرى، ايرانو -تورانى & 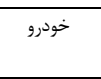 & زينتى \\
\hline VV & $\begin{array}{l}\text { Cotoneaster nummularioides } \\
\text { Pojark. }\end{array}$ & شيرخشت سكهاى & & ميكروفانروفيت & ايرانو -تورانى & 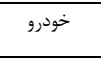 & زينتى- دارويى \\
\hline
\end{tabular}




\begin{tabular}{|c|c|c|c|c|c|c|c|}
\hline vı & Crataegus azarolus $\mathrm{L}$. & ز زانيكيالك زالى & يميشان & 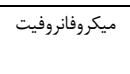 & ايرانو -تورانى، مديترانهاى & 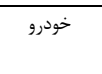 & زينتى-خوراكى \\
\hline vq & Crataegus microphylla K.Koch & زالزالك برك ريز، & 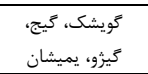 & 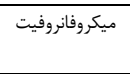 & ايرانو -تورانى & 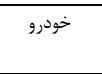 & زينتى، خوراكى - \\
\hline$\wedge \cdot$ & Crataegus pontica K.Koch & زالزالى كرجى & يميشان & 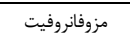 & ايرانو -تورانى & 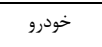 & زينتى-خوراكى \\
\hline$\wedge 1$ & Cydonia oblonga Mill. & ب اله، شال به، به & & ميكروفانروفيت & ايرانو -تورانى & 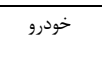 & خوراكى -دارويى \\
\hline Ar & $\begin{array}{l}\text { Malus domestica (Suckow) } \\
\text { Borkh. }\end{array}$ & سيب & 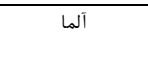 & ميكروفانروفيت & ارويا - سيبرى، ايرانو -تورانى & كاشته شده & خوراكى-دارويى \\
\hline Ar & Malus orientalis Uglitzk. ex Juz. & سيب، سيب & آلما، تالاسو & مزوفانروفيت & ايرانو -تورانى & 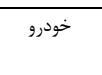 & خوراكى-دارويى \\
\hline Af & Prunus armeniaca $\mathrm{L}$. & ز ت مدآلو & & مزوفانروفيت & ايرانو -تورانى & كاشته شده & خوراكى-دارويى \\
\hline$\Lambda \Delta$ & Prunus avium (L.) L. & كيلاس، آلوكى & & 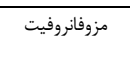 & ارويا - سيبرى، ايرانو -تورانى، & 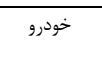 & خوراكى-دارويى \\
\hline$\wedge 9$ & Prunus cerasifera Ehrh. & آلوجه قرمز & & ميكروفانروفيت & ايرانو -تورانى، مديترانهاى & كاشته شده & خوراكى-دارويى \\
\hline Av & Prunus cerasus $\mathrm{L}$. & آلبالو & & مزوفانروفيت & ارويا - سيبرى، ايرانو -تورانى & 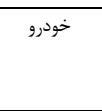 & 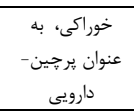 \\
\hline$\wedge 1$ & Prunus domestica $\mathrm{L}$. & $\begin{array}{c}\text { آلوزرد، آلوحه، } \\
\text { كوجه }\end{array}$ & 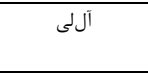 & مزوفانروفيت & ارويا - سيبرى، ايرانو -تورانى، & كاشته شده & خوراكى و دارويى \\
\hline 19 & Prunus dulcis (Mill.) D.A.Webb & بادام تلخ، بادام & آجىبادام، بادام، & مزوفانروفيت & ايرانو -تورانى، مديترانهاى & كاشته شده & زينتى، خوراكى - \\
\hline 9 . & Prunus incana (Pall.) Batsch & آل آلوى كوهى، & بيراليك & نانوفانروفيت & ايرانو -تورانى & 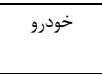 & خوراكى-دارويى \\
\hline 91 & $\begin{array}{l}\text { Prunus lycioides (Spach) } \\
\text { C.K.Schneid. }\end{array}$ & 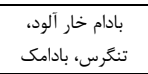 & بادامجه، بادامجىى & نانوفانروفيت & ايرانو -تورانى & خودرو & زينتى \\
\hline 94 & Prunus mahaleb L. & محلب & كنره & مزوفانروفيت & ايرانو -تورانى، مديترانهاى & 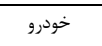 & خوراكى-دارويى \\
\hline q4 & Prunus persica (L.) Batsch & هلو، شفتالو & & ميكروفانروفيت & ايرانو -تورانى & 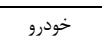 & خوراكى \\
\hline 94 & Prunus spinosa $\mathrm{L}$. & وآلوخه، كوجه، هلاله & & ميكروفانروفيت & ارويا - سيبرى، ايرانو -تورانى، & خودرو & خوراكى \\
\hline $9 \Delta$ & Pyracantha coccinea M.Roem. & شيرخشت آتشين، & & نانوفانروفيت & ايرانو -تورانى، مديترانهاى & كاشته شده & زينتى \\
\hline 99 & $\begin{array}{l}\text { Pyracantha crenulata (D.Don) } \\
\text { M.Roem. }\end{array}$ & كنيرّراى & & نانوفانروفيت & ايرانو -تورانى، مديترانهاى & كاشته شده & زينتى \\
\hline 9v & Pyrus boissieriana Buhse & كلابى تركَّانى، & 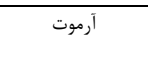 & ميكروفانروفيت & ايرانو -تورانى & 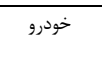 & خوراكى -دارويى \\
\hline 91 & Pyrus communis $\mathrm{L}$. & كَلابى، خج & & مزوفانروفيت & ايرانو -تورانى، مديترانهاى & كاشته شده & خوراكى -دارويى \\
\hline 99 & Pyrus syriaca Boiss. & كلابى سورى، & كركلابى، امرو، & مزوفانروفيت & ايرانو -تورانى & كاشته شده & خوراكى -دارويى \\
\hline $1 \cdots$ & Rosa canina $\mathrm{L}$. & نسترن وحَى، & 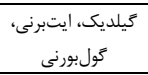 & ميكروفانروفيت & ارويا - سيبرى، ايرانو -تورانى، & 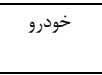 & زينتى -دارويى \\
\hline 1.1 & Rosa $\times$ damascenaMill. & كل محمدى، كل & قزيلكول & نانوفانروفيت & ايرانو -تورانى & 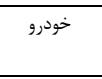 & زينتى، خوراكى - \\
\hline $1 . r$ & Spiraea crenata $\mathrm{L}$. & اسيره & شيليم & ن انوفانروفيت & ايرانو -تورانى & خودرو & زينتى \\
\hline \multicolumn{8}{|c|}{ بيديان Salicaceae } \\
\hline $1 \cdot r$ & Populus alba $\mathrm{L}$. & سبيدار، سفيدار، كبوه & 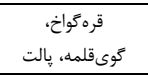 & مزوفانروفيت & ارويا - سيبرى، ايرانو -تورانى، & كاشته شده & زينتى- دارويى \\
\hline 1.4 & Populus euphratica Olivier & يده & قواخ، يِيرآغاجى & مزوفانروفيت & ايرانو -تورانى، مديترانهاى، صحرا & 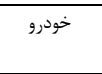 & زينتى \\
\hline $1 \cdot 0$ & Populus nigra $\mathrm{L}$. & تبريزى، شالك & قلمه، آغسويد & مزوفانروفيت & ارويا - سيبرى، ايرانو -تورانى، & كاشته شده & زينتى- دارويى \\
\hline 1.9 & Salix acmophylla Boiss. & زرد بيد & سووت، سويد، & ميكروفانروفيت & ايرانو -تورانى، صحرا - سندى & 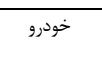 & 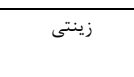 \\
\hline $1 \cdot V$ & Salix aegyptiaca $\mathrm{L}$. & بيد مشك & 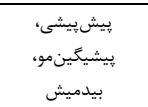 & مزوفانروفيت & ايرانو -تورانى & خودرو & زينتى- دارويى \\
\hline $1 \cdot 1$ & Salix alba $\mathrm{L}$. & بيد سفيد، فك & & مزوفانروفيت & ارويا - سيبرى، ايرانو -تورانى & كاشته شده & زينتى- دارويى \\
\hline 1.9 & Salix babylonica L. & بيد مجنون & & مزوفانروفيت & ايرانو -تورانى & كاشته شده & زينتى \\
\hline
\end{tabular}




\begin{tabular}{|c|c|c|c|c|c|c|c|}
\hline 11. & Salix excelsa J.F.Gmel. & سيد بيد مر تفع فوكا، & & 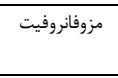 & ارويا - سيبرى، ايرانو -تورانى & 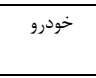 & $\begin{array}{l}\text { زينتى - خوراكى (تهيه آب نبات) } \\
\end{array}$ \\
\hline \multicolumn{8}{|c|}{ ناتركيان Sapindaceae } \\
\hline 111 & Acer negundo L. & افراى سياه، افراى & & مزوفانروفيت & ارويا - سيبرى & كاشته شده & زينتى \\
\hline $11 T$ & Acer platanoides $\mathrm{L}$. & افراى جنارى برى افرى & & مكافانروفيت & ارويا - سيبرى، ايرانو -تورانى، & كاشته شده & 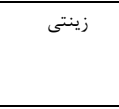 \\
\hline 114 & Acer pseudoplatanus $L$. & افراى شبه جنارى & & مزوفانروفيت & ارويا - سيبرى، ايرانو -تورانى، & كاشته شده & زينتى \\
\hline 114 & Koelreuteria paniculata Laxm. & باران طلايى & & مزوفانروفيت & آسياى شرقى & كاشته شده & زينتى \\
\hline \multicolumn{8}{|c|}{ كلميمونيان Scrophulariaceae } \\
\hline 110 & Buddleja davidii Franch. & دم موشى قفايى & & ميكروفانروفيت & ايرانو -تورانى، آسياى شرقى & كاشته شده & زينتى \\
\hline \multicolumn{8}{|c|}{ عرعريان Simaroubaceae } \\
\hline 119 & $\begin{array}{l}\text { Ailanthus altissima (Mill.) } \\
\text { Swingle }\end{array}$ & عرعر & & مزوفانروفيت & آسياى شرقى & كاشته شده & زينتى- دارويى \\
\hline \multicolumn{8}{|c|}{ كزيان Tamaricaceae } \\
\hline 118 & Tamarix dubia Bunge & كز مشكوى & آغاجى، يورلغون، يورقون & ميكروفانروفيت & ايرانو -تورانى، صحرا - سندى & كاشتهشده & زينتى \\
\hline \multicolumn{8}{|c|}{ نارونيان Ulmaceae } \\
\hline 111 & $\begin{array}{l}\text { Ulmus carpinifolia var. } \\
\text { umbraculifera (Trautv.) Rehder }\end{array}$ & نارون حترى & 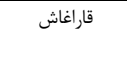 & 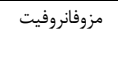 & ايرانو -تورانى & خودرو & زينتى- دارويى \\
\hline 119 & Ulmus glabra Huds. & ملج & قرهآغاج & مكافانروفيت & ارويا - سيبرى، ايرانو -تورانى & خودرو & 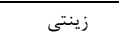 \\
\hline IT. & Ulmus minor Mill. & 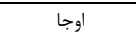 & & مزوفانروفيت & ايرانو -تورانى، مديترانهاى & 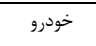 & زينتى- دارويى \\
\hline \multicolumn{8}{|c|}{ انكوريان Vitaceae } \\
\hline$|r|$ & $\begin{array}{l}\text { Parthenocissus quinquefolia (L.) } \\
\text { Planch. }\end{array}$ & مو حسب & & مزوفانروفيت & ارويا - سيبرى & كاشته شده & زينتى \\
\hline ITK & Vitis vinifera $\mathrm{L}$. & انكور & اوزوم، غوره & مكافانروفيت & ايرانو -تورانى، مديترانهاى & كاشته شده & خوراكى -دارويى \\
\hline
\end{tabular}

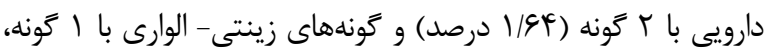

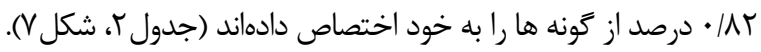

بحث

يزوهش حاضر نخستين مطالعه به منظور معرفى گونههاى

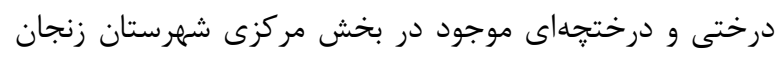

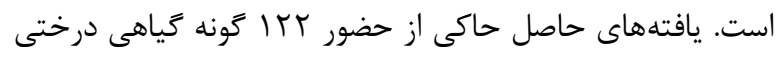

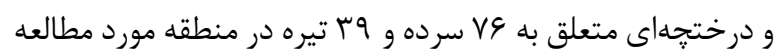

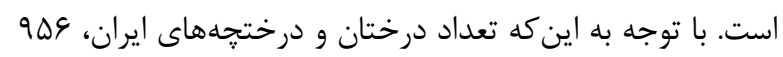

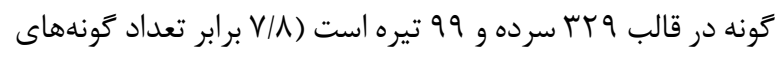

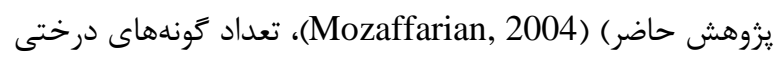

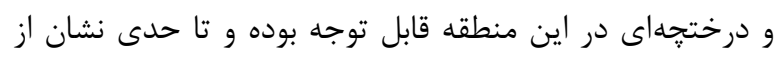

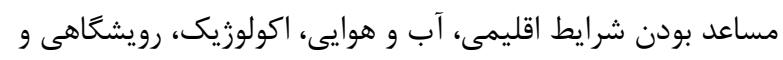
ادافيك منطقه مورد مطالعه دارد.

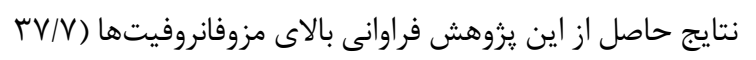

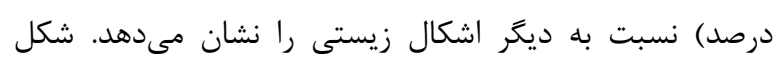

ايرانو-تورانى/آسياى شرقى با ه كَونه ( / / درصد)، مديترانهاى با F كَونه

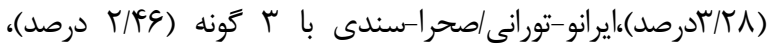

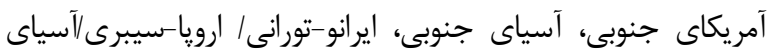

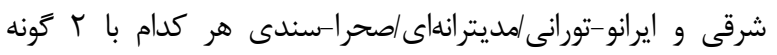

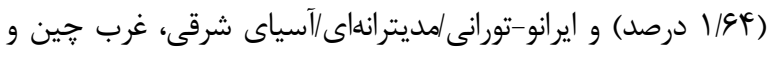

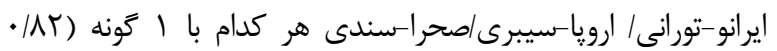

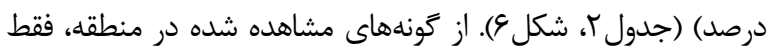
كونه . Prunus lycioides (Spach) C.K.Schneid انحصارى كشور ايران است. درختان و درختجههاى منطقه بر حسب نوع استفاده به

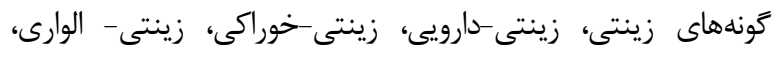

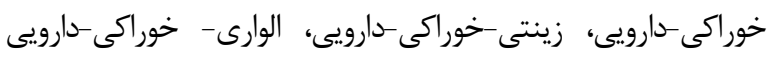

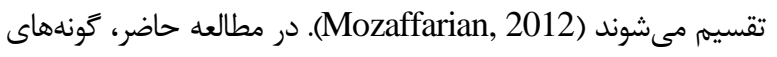

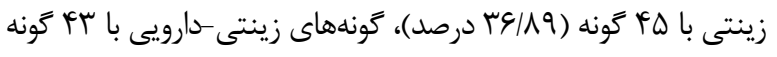
(

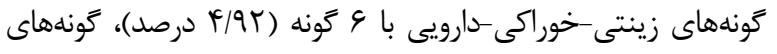

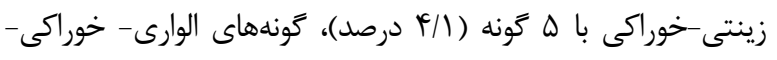


از منطقه شرايط اكولوزيك مناسبى براى استقرار كونههاى آبدوست ارويا-سيبرى را فراهم نموده است. بخشهاى يُ يايين

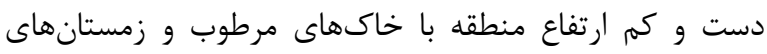
معتدل يا با سرماى كم براى رويش كونههاى مديترانهاى مناس هستند (Payandeh et al., 2016). در اين منطقه، با كونه متعلق به ناحيه مديترانهاى و ها گونه با ساير نواحى فيتوجغرافيايى

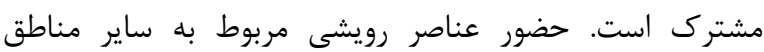

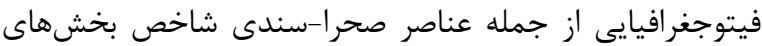

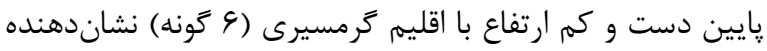
انعطاف يذيرى بالاى اكولوزيك و قابليت حمايتى خوب اين اين منطقه براى گسترش عناصر رويشى متعلق به انواع كوروتايڤها است. از إنائ

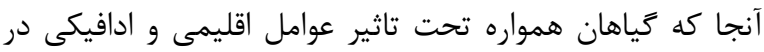
طول زمان تغيير يافته و داراى ويزَّى اكولوزيك خاص و دامنه أنه

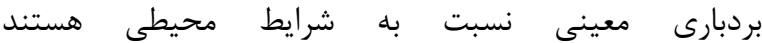
(Nejadhabibvash et al., 2016)، بهنظر مى سئرسد بخشى از كياهان موجود در منطقه نيز تا حدودى با شرايط محيطى بارئ

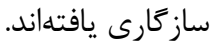

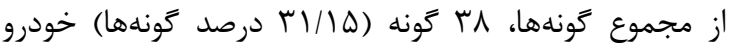

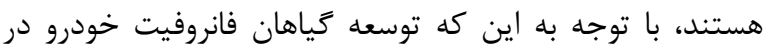
اكوسيستمها نيازمند فراهم بودن تمهيداتى جون خاك، دما و وتاني منابع آبى مناسب است، اين موضوع بيانكر شرايط محيطى مناسب توني

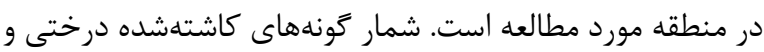

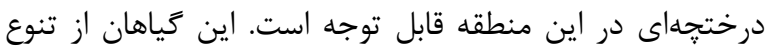

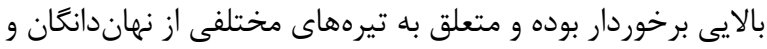

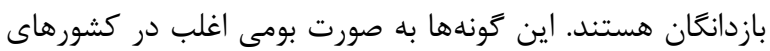

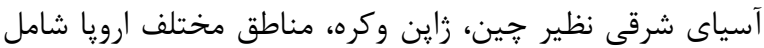
اروياى مركزى، شرقى، جنوبى، كشورهاى حوزه آمريكاى شمالى

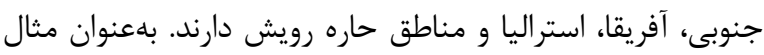

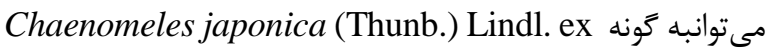
Forsythia × intermedia Zabel بومى زاين، كونه Spach Koelreuteria paniculata Laxm. بومى جين و زإين، كونه

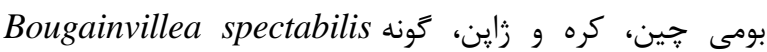
Araucaria araucana (Molina) بومى برزيل، كونه Juniperus horizontalis بومى شيلى وخونهاي، كونه K.Koch Maclura pomifera (Raf.) C.K.Schneid. ،Moench Parthenocissus quinquefolia (L.)Planch.و اشاره كرد. از گونهاى درختى غيرمثمر، بزرى و سايهدار در كنار

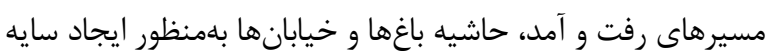
و جلوكيرى از نفوذ هواى كرم و گردوخاك، از كياهان كلدار

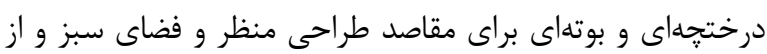

زيستى كياهان بر اساس سازكارى ريختشناختى آنها با شرايط

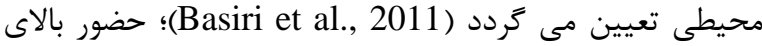
اين شكل زيستى حاكى از شرايط مناسب رويشى ورد و منابع آبى و

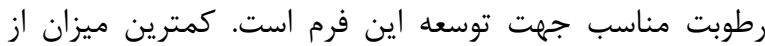
فراوانى شكل زيستى مربوط به فرم مكافانروفيت است. توسعه اين

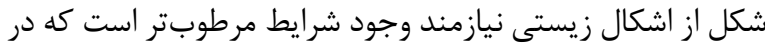
اين منطقه موجود نيست.

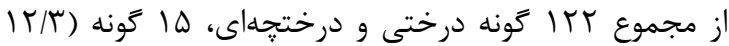
درصد) به بازدانكان تعلق دارند كه كاشتهشده هستند. با توجه به دانه

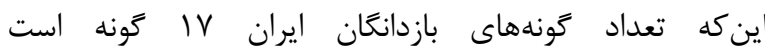
(Ghahremaninejad et al., 2017)، تعداد بازدانكان كاشته شده در بخش مركزى شهرستان زنجان قابل توجه است. در ميان

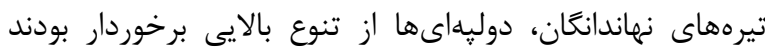

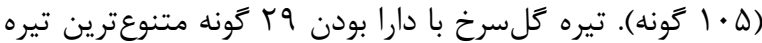

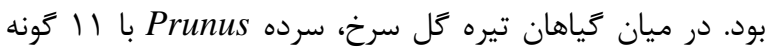

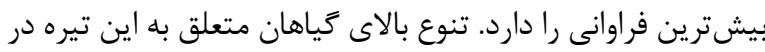
مطالعات مربوط به ساير مناطق نيز مشاهده شده است Mozaffarian, 2004; Ravanbakhsh \& Etemad, 2008; ) Azzar et al., 2012; Tabad et al., 2016; Pahlavani et درختان و درختجههاى تيره گلسرخ از ساز كارىهاى (al., 2017

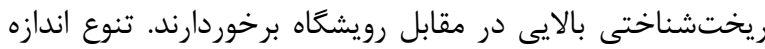

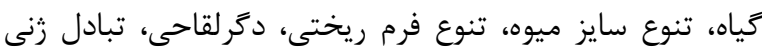

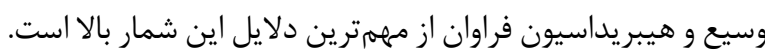
جِ از تيره كل سرخ، تيره زيتون دومين تيره فراوان منطقه است.

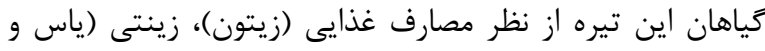
ياس بنفش) و فضاى سبز (زبان كنجشك) حائز اهميت هستند.

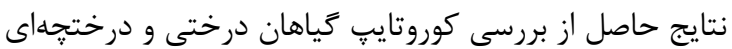

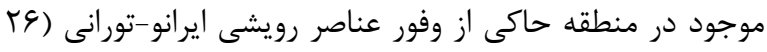

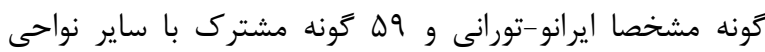

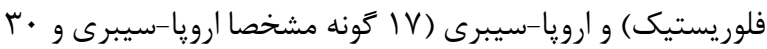
كونه مشترك با ساير نواحى فلوريستيك) است كه البته با توجه به اله

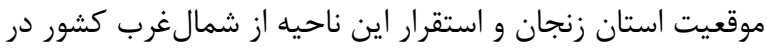

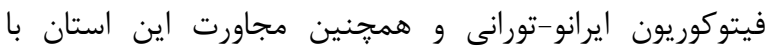

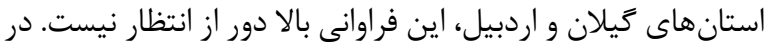

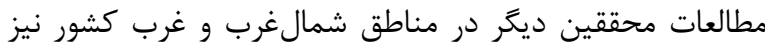

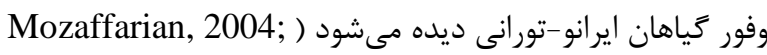
Yusefi, 2006; Tabad et al., 2016

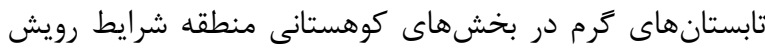

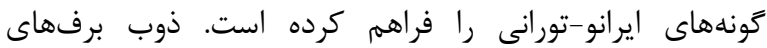

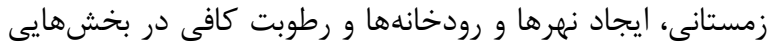




\section{REFERENCES}

APG IV. 2016. An update of the Angiosperm phylogeny group classification for the orders and families of flowering plants: APG IV. Bot. J. Linn. Soc. 181: 1-20.

Assadi, M. et al. (eds.). 1988-2018. Flora of Iran. Vols.1149. RIFR, Tehran.

Azzar, A., Siami, A., Khara, J. \& Valizadegan, O. 2012. Study of diversity of trees and shrubs of Naghadeh County (Soldooz) in West Azerbaijan province. $2^{\text {th }}$ National Congress of Biodiversity and its effect on Agriculture and Environment, Urmia, Iran.

Basiri, R., Taleshi, H., Poorrezaee, Hassani, S.M. \& Gharehghani, R. 2011. Flora, life form and chorotypes of plants in river forest Behbahan, Iran. ME. J. Sci. Res. 2: 246-252.

Davis, P.H. (ed.). 1965-1988. Flora of Turkey and the east Aegean islands. Vols. 1-10. Edinburgh University Press, Edinburgh, Scotland.

Esmailzadeh, O., Hosseini, S. M., Asadi, H., Ghadiripour, P. \& Ahmadi, A. 2012. Plant biodiversity in relation to physiographical factors in Afratakhteh Yew (Taxus baccata L.) Habitat, NE Iran. J. Plant. Biol. 12: 1-12.

Ghahremaninejad, F., Ataei, N. \& Nejad Falatoury, A. 2017. Comparison of angiosperm flora of Afghanistan and Iran in accordance with APG IV system. Nova Biol. Reperta 4: 73-97.

Ghanbari, S. \& Sheidai Karkaj, E. 2018. Diversity of tree and shrub species in woodlands of Guijeh-bel region of Ahar. Iranian J. Forest Poplar Res. 1: 118-128.

Golchin, A. 2007. Effect of heavy metals on rangelands and livestock in Zanjan Province. Agricultural Jihad organization, agricultural and natural resources research center of Zanjan Province, management and planning organization of Zanjan Province, $89 \mathrm{pp}$.

Hosseini, A. 2014. Diversity of tree and shrub species in relation to topographic factors and stand characteristics in Persian oak forests of Ilam province. (Case study; Miantang forests in Sirvan). J. Pl. Res. 2: 194-203.

Hosseini, A. 2016. Gradient effect of altitude on the diversity of tree species in oak forests of Hayanan, Ilam. J. Nat. Ecosys. Iran. 1: 1-8.

Hui, G. \& Pommerening, A. 2014. Analyzing tree species and size diversity patterns in multi-species unevenaged forests of Northern China. Forest Ecol. Managem. 316: $125-138$.

IPNI. 2016. The International Plant Names Index. Retrieved from http://www.ipni.org. On: 3 December 2016.

Javnshir, K. 1976. Atlas of woody plants of Iran. National Society of Natural Resources and Human Environment Conservation, Tehran, 163pp.

Komarov, V.L. (ed.). 1933-1964. Flora of U.S.S.R. Vols. 1-30. Akademiya Nauk SSSR, Moscow and Leningrad.

Krebs, C.J. 2001. Ecology: The experimental analysis of distribution and abundance. Benjamin Cummings, Sanfransisco, 608 pp.

Larti, M., Gasempour, S. \& Maassoumi, A.A. 2011. Trees and shrubs in Marmisho area in West Azarbaijan. Iran. J. Biol. 1: 104-109.
درختان ميوهدار بلمنظور استفاده از ميوه آنها براى مصارف

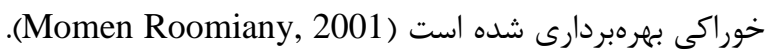

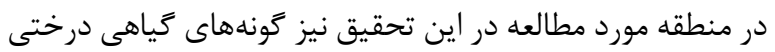

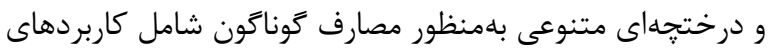

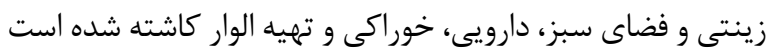

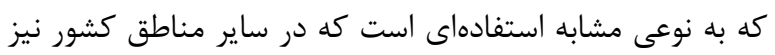

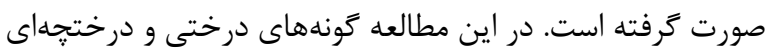

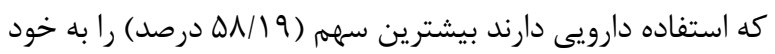

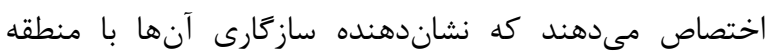

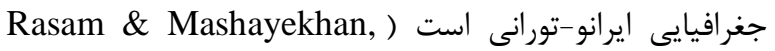

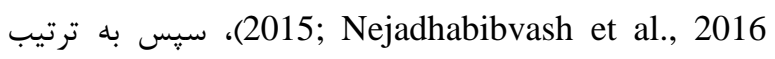
كونههاى زينتى وخوراكى قرار دارند.

$$
\text { سياسگزارى }
$$

نويسندكان مقاله ازكاركنان اداره كل هواشناسى استان زنجان بلويزه خانم سكينه امامى، اداره كل منابع طبيعى و آبخيزدارى إنى إنسان

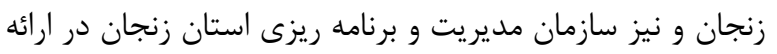

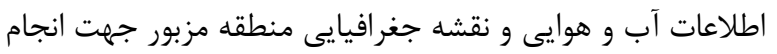
اين يزوهش قدردانى مى كنند. 
Momen Roomiany, E. 2000. Introduction of one Hundred species of trees and shrubs suitable for landscape design. Research Institute of Forests and Rangelands Publications, Tehran, $118 \mathrm{pp}$.

Mousavi, A. 2000. Final report of research project of collection and identification of plants of Zanjan province and establishment of herbarium in research center of natural resources and livestock affairs of Zanjan province. Research Center of Natural Resources and Livestock Affairs of Zanjan province, $205 \mathrm{pp}$.

Mozaffarian, V. 1998. A dictionary of Iranian plant names. Farhang-e Moaser Publication, Tehran, 740 pp.

Mozaffarian, V. 2000. Plant classification. Vols. 1-2. Amir Kabir Publications, Tehran, 1111 pp.

Mozaffarian, V. 2004. Trees and shrubs of Iran. Farhange Moaser Publications, Tehran, 1003 pp.

Mozaffarian, V. 2012. Study of medicinal and aromatic plants of Iran. Farhang-e Moaser Publications, Tehran, $1444 \mathrm{pp}$.

Nejadhabibvash, F., Makali, H. \& Rezaei Chiyaneh, E. 2016. Flora, life form and chorology of plants in Razhan protected area in West Azerbaijan Province. Taxon. Biosyst. 27: 85-95.

Pahlavani, A. H., Aminirad, M. \& Sajedi, S. 2017. Trees and shrubs of plant Protection Research Institute. - Iranian Research Institute of Plant Protection, Tehran, $179 \mathrm{pp}$.

Payandeh, M., Bordbar, F. \& Mirtadzadini, S.M. 2016. Floristic strudy of Hanza-kuh of Bahr-Aseman protected area (SE Iran). Taxon. Biosyst. 28: 79-100.

Proença, V., Martin, L.J., Pereira, H.M., Fernandez, M., McRae, L., Belnap, J., Böhm, M., Brummitt, N., García-Moreno, J., Gregory, R.D., Honrado, J.P.,
Jürgens, N., Opige, M., Schmeller, D.S., Tiago, P. \& Van Swaay, C.A.M. 2017. Global biodiversity monitoring: from data sources to essential biodiversity variables. Biol. Conserv. 213: 256-263.

Rasam, Gh.A. \& Mashayekhan, A. 2015. Studying of floristic, life form and chorology of medicinal plants in Shirvan natural cosystems. J. Pl. Ecosys. Conserv. 6: 27-42.

Raunkiaer, C. 1934. The life forms of plants and statistical plant geography. Clarendon Press, Oxford, 632 pp.

Ravanbakhsh, H. \& Etemad, V. 2008. Recognition and introduction of natural forests stands of Tehran province. JES 46: 19-32.

Rechinger, K.H. (ed.). 1963-2015. Flora Iranica. 1-174: Akademische Druck- u. Verlagsanstalt, Graz; 175: Akademische Verlagsgesellschaft, Salzburg; 176-181: Naturhistorisches Museum, Wien.

Tabad, M.A., Jalilian, N. \& Maroofi, H. 2016. Study of flora, life form and chorology of plant species in Zarivar region of Marivan, Kurdistan. Taxon. Biosyst. 29: 69-102.

Takhtajan, A.L. 1986. Floristic regions of the world. University of California Press, Berkeley, 544 pp.

The Plant list (version1.1). Retrieved from http://www.the plantlist.org. On: 3 September 2013.

Yusefi, M. 2006. Flora of Iran. Payam-e Noor University Publications, $227 \mathrm{pp}$.

Zohary, M. 1973. Geobotanical foundations of the Middle East. Geobotanica Selecta, vols.1-2. Gustav Fisher Verlag, Stuttgart, Swets \& Zeitlinger, Amsterdam, 739 pp.

How to cite this article:

Toghranegar, Z. \& Vafadar, M. 2020. Introduction of tree and shrub plant species in the central district of Zanjan County. Nova Biologica Reperta 7: 119-132. (In Persian).

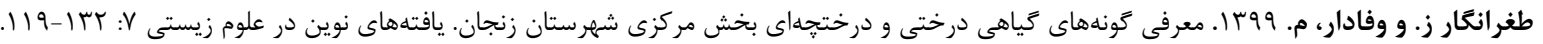

